\title{
Seascape connectivity of Gulf sturgeon Acipenser oxyrinchus desotoi population units across the northern Gulf of Mexico
}

\author{
Page E. Vick ${ }^{1, *}$, Mark S. Peterson ${ }^{1}$, William T. Slack ${ }^{2}$ \\ ${ }^{1}$ Department of Coastal Science, School of Ocean Science and Engineering, The University of Southern Mississippi, \\ Ocean Springs, MS 39564, USA \\ ${ }^{2}$ US Army Engineer Research and Development Center, Environmental Laboratory EEA, Vicksburg, MS 39180, USA
}

\begin{abstract}
Critical habitat was designated in 2003 for federally threatened anadromous Gulf sturgeon to aid in population recovery. This study examined overwintering Gulf sturgeon spatial use and movement through critical habitat monitored by the Ship Island acoustic array from 2011 to 2015. Previous studies observed western population Gulf sturgeon (Pearl and Pascagoula rivers) overwintering near the ends and within the passes of the barrier islands of the Mississippi Sound, USA. Recent telemetry studies detected eastern population fish (Escambia, Blackwater, Yellow, and Choctawhatchee rivers) overwintering as far west as Mobile Bay, Alabama; however, this study is the first to observe eastern population fish overwintering in western population critical habitat associated with the Ship Island array. Use of overwintering habitat was compared using mean active days detected and rate of travel to and from the array. There was no significant difference in mean active days of population units on the array; however, travel rate to the array from natal drainages was significantly different, with eastern population individuals traveling at a faster rate compared to western population individuals. Post hoc tests indicated that individuals from the Blackwater River had a significantly higher travel rate compared to Pascagoula River individuals. We documented large-scale seascape connectivity among population units of Gulf sturgeon across the northern Gulf of Mexico. Although large-scale seascape connectivity promotes mixing among population units and an exchange of marine nutrients into riverine environments, large-scale migration poses an issue for endangered species such as Gulf sturgeon, as there is greater risk of bycatch mortality and size-specific predation.
\end{abstract}

KEY WORDS: Acoustic telemetry · Threatened species $\cdot$ Critical overwintering habitat $\cdot$ Migration

\section{INTRODUCTION}

Life history characteristics and environmental impacts combine to slow the recovery of threatened Gulf sturgeon Acipenser oxyrinchus desotoi populations. Gulf sturgeon are slow-growing, late-maturing anadromous fish (LeBreton \& Beamish 2004) that use multiple freshwater and marine habitats throughout all life stages, allowing for interactions with many detrimental natural and anthropogenic events. Population loss has occurred directly through overfishing, hurricanes, red tide, hypoxia, and oil spills (Parauka

${ }^{*}$ Corresponding author: page.vick@noaa.gov et al. 2011, Rudd et al. 2014, USFWS 2015) and indirectly through habitat loss caused by coastal development, dam and sill construction, dredging, and storm events (Heise et al. 2005, Ahrens \& Pine 2014). Coastal development, incidental bycatch, and historic overfishing (harvest banned in 1974; reviewed in USFWS \& GSMFC 1995, Sulak et al. 2016) in combination with storm activity have also reduced the current range of Gulf sturgeon. Historically, Gulf sturgeon populations ranged from the Mississippi River to Tampa Bay, Florida; the current reduced range is from the Pearl River in Louisiana to the

(C) P.E.V., M.S.P., and outside the USA, the US Government 2018. Open Access under Creative Commons by Attribution Licence. Use, distribution and reproduction are unrestricted. Authors and original publication must be credited.

Publisher: Inter-Research · www.int-res.com 
Suwannee River in Florida (Wooley 1985, USFWS 1991). The current distribution is grouped regionally into western (Pearl and Pascagoula river systems) and eastern (Escambia, Yellow, Blackwater, Choctawhatchee, Apalachicola and Suwannee river systems) population units separated geographically by Mobile Bay, Alabama (Dugo et al. 2004). These regional groupings or population units are supported by population structure; drainages within the same population unit show close genetic relationships for the Gulf sturgeon, as the population structure of the species occurs at the drainage level (Dugo et al. 2004).

Delineating connectivity among habitats or ecosystems has been a major focus of community and ecosystem ecology in recent decades, and studies have focused on small- to large-scale patterns (Garman \& Macko 1998, Naiman et al. 2002, Ray 2005, Merz \& Moyle 2006, Sheaves 2009, Berkström et al. 2013, Bryan-Brown et al. 2017, Schindler \& Smits 2017). In many ecosystems, regional connectivity has been addressed but rarely on large-scale patterns. For example, regional connectivity of marine and freshwater environments occurs seasonally as offshore-onshore migrations throughout the life of Gulf sturgeon and these migrations are driven by environmental cues, like changes in water temperature, day length, water discharge, and barometric pressure (Heise et al. 2004, Grammer et al. 2015, Sulak et al. 2016). From late February to early April, spawning-capable adult fish travel to the upper reaches of their natal rivers to spawn in areas characterized by hard bottoms with clean substrata such as gravel and cobble (Sulak \& Clugston 1998, Fox et al. 2000, Heise et al. 2004). Spawning-capable fish enter rivers earlier than nonspawning fish (Fox et al. 2000, Heise et al. 2004); nonspawning and post-spawning fish occur in downstream summer holding areas beginning in late May and remain there until fall emigration begins in midSeptember (Heise et al. 2004, 2005). Summer holding areas are usually near deep river bends or upriver from sand shoals (Wooley \& Crateau 1985, Heise et al. 2005, Grammer et al. 2015), and environmental cues direct fish to move from summer holding areas to fall staging areas, which are characterized by low salinity, allowing the fish to acclimate to marine waters (Heise et al. 2005, Grammer et al. 2015). Subsequently, during fall outmigration, all size classes, excluding young-of-the-year, move out of the river and into the estuary, where juveniles and small subadults remain and feed. In contrast, large sub-adults and adults enter more saline waters of the nearshore environment to forage during overwintering periods (Mason \& Clugston 1993, Brooks \& Sulak 2005,
Havrylkoff et al. 2012, Peterson et al. 2013, 2016, 2018). All adult and sub-adult fish immigrate into freshwater rivers and repeat this annual cycle (Fox et al. 2000, Heise et al. 2004, Havrylkoff et al. 2012). Maintaining this connectivity to all environments is essential to Gulf sturgeon population recovery (Manson \& Hogarth 2003).

Once in marine environments, alongshore movement, rather than offshore-onshore movement, usually occurs close to natal river drainages in shallow waters (Parauka et al. 2011). Emigration distance varies greatly by individual, with some individuals traveling up to $315 \mathrm{~km}$ in one direction (Edwards et al. 2007, Ross et al. 2009, Sulak et al. 2009, Parauka et al. 2011, USFWS 2015). Rate of travel also varies by individual and can be difficult to define, as the fish may travel steadily to the overwintering habitat or may travel in short bursts (Parauka et al. 2011).

Individuals from multiple river systems but within the same population unit (see Dugo et al. 2004) have been detected in the same overwintering habitat (Edwards et al. 2007, Rogillio et al. 2007, Ross et al. 2009); however, this co-occurrence has rarely been observed among eastern and western population units (Parauka et al. 2011, Havrylkoff et al. 2012, USFWS 2015, Peterson et al. 2018, Vick et al. 2018). Small-scale straying of immigrating Gulf sturgeon into non-natal drainages within their population unit may occur; these drainages are spatially close to their natal drainage and the fish within these drainages are more genetically similar to Gulf sturgeon within their natal drainage. Large-scale non-natal immigration of Gulf sturgeon into drainages within a different population unit is rare (Stabile et al. 1996, Dugo et al. 2004, Parauka et al. 2011). Furthermore, overwintering studies which focused on the western population unit have document co-occurrences between the Pearl and Pascagoula rivers but co-occurrences of western population unit individuals with eastern population unit individuals have rarely been recorded. For example, manually tracked Gulf sturgeon of the western population were observed along the barrier islands bordering the Mississippi Sound; they were found concentrated near the island ends and passes (Rogillio et al. 2007, Ross et al. 2009). In contrast, an adult Yellow River fish (eastern population, about $164 \mathrm{~km}$ from natal drainage) was detected in the Pascagoula estuary, indicating co-occurrences by multiple population units in western population estuarine critical habitat (Parauka et al. 2011, Havrylkoff et al. 2012), and 2 adult fish from eastern population units (Escambia and Choctawhatchee rivers) were detected in nearshore areas off Gulfport, Mississippi 
(about 170 and $252 \mathrm{~km}$, respectively, from the natal drainage terminus), in April 2014 (Peterson et al. 2018).

Large sub-adult and adult Gulf sturgeon overwintering in marine habitats translocate marine carbon (e.g. benthic prey) back to their natal river, functionally connecting freshwater and marine environments as has been documented in Bering Sea salmonids (Oncorhynchus spp.), eastern US clupeids, and Pacific Chinook salmon O. tschawytscha (Garman \& Macko 1998, Ray 2005, Merz \& Moyle 2006) as well as among habitat types (Sheaves 2009, Berkström et al. 2013, Bryan-Brown et al. 2017). In addition to striped bass Morone saxatilis and Alabama shad Alosa alabamae (Mickle et al. 2010), Gulf sturgeon likely transport nutrients during spring immigration, as individual fish deposit marine carbon into the freshwater environment via excretion, reproduction, and death (sensu Naiman et al. 2002, Schindler \& Smits 2017). Stable isotope analyses of Gulf sturgeon in freshwater environments indicate the presence of marine carbon in muscle tissue, displaying this important connectivity pattern between freshwater and marine habitats (Gu et al. 2001, Sulak et al. 2012). This marine carbon input links distant Gulf sturgeon habitats such as barrier islands to natal rivers (Altinok \& Grizzle 2001, Sulak et al. 2012). Thus, Gulf sturgeon can be viewed as part of a larger meta-community formed by links of interacting organisms among local communities or through spatial and temporal connectivity (Leibold et al. 2004). To ensure that vital connectivity between environments remains for this anadromous species, habitat must be protected (or restored) in both environments.

The US Army Corps of Engineers (USACE) is currently restoring Ship Island to pre-hurricane conditions (details in Vick et al. 2018). Since this restoration effort is occurring within designated Gulf sturgeon critical habitat, the overall objective of this study was to document spatial use and movement of Gulf sturgeon in areas monitored by the Ship Island acoustic array. We hypothesized that there would be limited small-scale use of the spatial extent/habitat occupied by the Ship Island array by members of the eastern population unit compared to members of the western population unit, as the array is closer $(\mathrm{km})$ to individuals from the western population. Specifically, we (1) estimated and compared spatial use (i.e. active days) on the Ship Island array by eastern and western population units detected between 2011 and 2015, and (2) quantified and compared movement (i.e. travel time, distance traveled, rate of travel) of western and eastern population units across the seascape in the northern Gulf of Mexico through the critical overwintering time frame (late October to late April).

\section{MATERIALS AND METHODS}

\author{
Western population unit capture, \\ handling, and tagging
}

Western population Gulf sturgeon were captured and processed during fall outmigration from 2011 to 2014 following NOAA protocols (Baremore \& Rosati 2013, Peterson et al. 2016). Anchored multifilament $(60.9 \times 3.0 \mathrm{~m}, 20.3 \mathrm{~cm}$ bar mesh or $45.7 \times 3.0 \mathrm{~m}, 12.7 \mathrm{~cm}$ bar mesh) and monofilament $(71.0 \times 2.4 \mathrm{~m}, 5.1 \mathrm{~cm}$ bar mesh) gillnets were set parallel and perpendicular to the flow in both the Pearl and Pascagoula river systems (western population unit), and nets were checked every 2 h (Peterson et al. 2016). Captured Gulf sturgeon were weighed (to nearest $0.1 \mathrm{~kg}$ ), measured for fork and total length (FL and TL, mm), and assessed for external tags and internal passive integrated transponder (PIT) tags; each new capture was tagged with T-bar and PIT tags (Heise et al. 2004). Sub-adult (891-1250 mm FL) and adult (>1251 mm FL) Gulf sturgeon were tagged with V13 (external) or V16 (internal) acoustic transmitters (Model V13-1L or V16-6H; $69 \mathrm{kHz} ; 3$ or 7 yr battery life with 90 s mean random delay; Vemco), respectively. Of the 71 captured Gulf sturgeon, 63 individuals were tagged with acoustic transmitters in the Pascagoula River. Adult Gulf sturgeon were not sexed, as they do not exhibit external sexually dimorphic features, and they were likely postspawning individuals preparing for fall outmigration. Tagging information and protocols are described in detail in Vick et al. (2018). Transmitters were detected if the fish swam within $300 \mathrm{~m}$ of the VR2W receivers of the Ship Island array; we assumed a 300 m detection range based on a previous range study in the nearshore sandy bottom habitat of Pensacola, Florida (Robydek \& Nunley 2011).

\section{Ship Island acoustic array}

Acoustically tagged Gulf sturgeon from western and eastern population units were detected on the acoustic telemetry array during 4 deployment monitoring periods (September through June 2011 to 2015; 'Methods' in Supplement 1 at www.int-res.com/ articles/suppl/n037p195_supp.pdf). The array consisted of 21 to 39 Vemco VR2W (69 kHz) receivers during its deployment (Fig. 1). Array construction, receiver attachment, deployment, and locations are described in Vick et al. (2018) and in Fig. 1 \& 'Methods' in Supplement 1. Data recorded on VR2W receivers were downloaded monthly. 


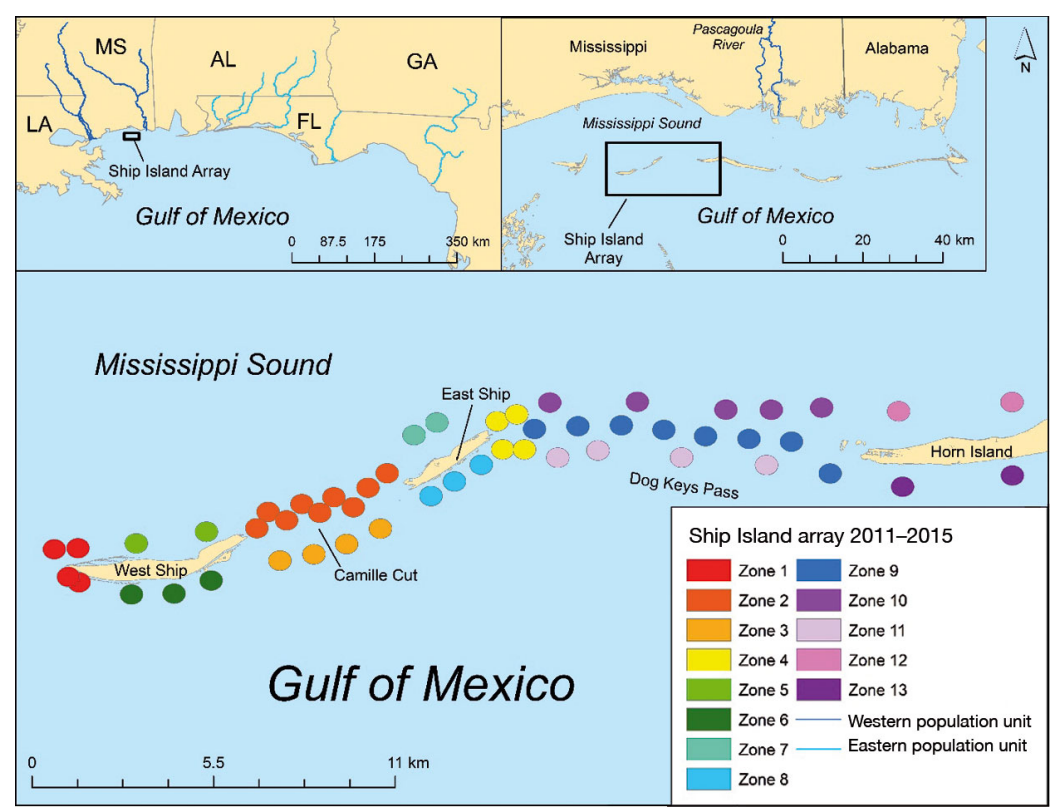

Fig. 1. Ship Island array delineated by zone, 2011 to 2015. Each circle represents a VR2W receiver and its $300 \mathrm{~m}$ detection radius. The upper left panel illustrates both east (pale blue) and west (dark blue) core rivers (population units) and general location of Ship Island; river names from west to east are Pearl, Pascagoula, Escambia, Blackwater, Yellow, Choctawhatchee, Apalachicola, and Suwannee. The upper right panel is an enlargement of the western population unit and Ship Island sturgeon migrating from western and eastern natal rivers. Raw data were filtered for false detections and duplicate detections prior to analysis. Data management methods are fully described in Peterson et al. (2016) and Vick et al. (2018); VR2W receivers were checked monthly for clock drift. For the first objective (estimation of spatial use), we used the data set compiled for all VR2W receivers in the Ship Island array (zones 1-13; Fig. 1). For the second objective (providing conservative estimates of travel rates), we used the information obtained from all original tagging sources as described in the previous subsection to calculate conservative time (d) and distance $(\mathrm{km})$ traveled by each fish and, therefore, the rate of travel $\left(\mathrm{km} \mathrm{d}^{-1}\right)$ during the monitoring period.

\section{Data analysis}

Spatial use of Ship Island array

\section{Gulf sturgeon data request}

As many of the Gulf sturgeon detected on the Ship Island array were Pearl River fish $(\mathrm{n}=15)$ and transients from the eastern population unit $(\mathrm{n}=26)$, we requested capture data from the tag owners who initially tagged these individuals. To follow Gulf sturgeon migration to the Ship Island array, the GPS locations of the nearest natal river mouth receivers and the dates of the fish leaving and re-entering the original natal river (last detection leaving the natal array and first detection re-entering the natal array during seasonal migration) were required. All natal drainage termini were equipped with receivers. Tag owners confirmed the original date and location of capture, TL (mm), FL (mm), and weight (to the nearest $0.1 \mathrm{~kg}$ ) along with any recapture information of the detected Gulf sturgeon. Data were also retrieved using NOAA's Gulf sturgeon database (https://grunt. sefsc.noaa.gov/gsp/index.jsp).

\section{Data management}

Large telemetry datasets were organized and used to examine spatial use of Ship Island by Gulf
Spatial use of the area monitored by the Ship Island array was compared by population unit using the mean number of active days on the Ship Island array. We determined an active day to be at least 2 consecutive detections of an individual on a single VR2W receiver. Because an individual Gulf sturgeon may swim in and out of the area monitored by the Ship Island array during any monitoring period, we wanted to consider the total number of active days the individual fish spent within the area monitored by the array throughout a monitoring period; we did not consider diel patterns. We considered any detection or set of detections from the same uniquely tagged Gulf sturgeon during 1 monitoring period to be a unique individual in all subsequent calculations; if the same uniquely tagged fish returned in a following monitoring period, then it was also considered a unique individual in the calculations. For each population unit, the total number of active days for all unique individuals detected on the array was summed across all monitoring periods (2011-2015) and then averaged by the total number of unique individuals detected. Population units were compared by mean active days on the entire Ship Island array using a Mann-Whitney $U$-test, as the data were 
non-normal and heterogeneous. Arrival and departure dates of each population unit were also observed for each monitoring period.

In contrast, differences in spatial use of Ship Island by population unit were estimated by active fish per receiver and active days per receiver. We considered two consecutive detections of a unique individual Gulf sturgeon on a single receiver as an active fish as well as an active day. Active fish per receiver was calculated by the total number of active fish of a population unit detected on a single receiver averaged by the total number of monitoring periods of the receiver ('Methods' in Supplement 1). For example, if 12 fish from the eastern population unit were detected on a receiver in zone 2 , then, on average, there would be 4 eastern population unit fish on that receiver. Similarly, active days per receiver were calculated by the total active days of a population unit detected on a single receiver averaged by the total number of monitoring periods of the receiver. For example, if the total number of active days of the western population unit on a receiver in zone 2 was $60 \mathrm{~d}$ over the entire monitoring period, then, on average, there were 20 active days on that receiver. Monitoring periods associated with the receivers are as follows: receivers in zones 1 and 4 had 4 monitoring periods; receivers in zones 2,3 , and 5 had 3 monitoring periods; receivers in zones 6 through 9 had 2 monitoring periods; and receivers in zones 10 through 12 had 1 monitoring period ('Methods' in Supplement 1).

\section{Rate of travel}

Travel time

Conservative travel times entering and exiting the Ship Island array were estimated for each detected individual, if the information was available. We considered entry to be the first detection of the individual on the Ship Island array during the fall emigration period, while we considered exit to be the last detection on the Ship Island array during the spring immigration period. The conservative time traveled for entry was estimated by the difference in total time (d) from the last detection on the natal drainage array and the first detection on the Ship Island array. Exit travel time was conservatively estimated by the difference in total time (d) from the last detection of the Ship Island array and the first detection on the natal drainage array. As previously noted, some Gulf sturgeon stray when immigrating to freshwater, meaning the drainage the fish returns to in the spring may not be its natal drainage but is within the same estuarine system.

\section{Travel distance}

The conservative distance traveled $(\mathrm{km})$ entering and exiting the array by individual fish was estimated using the latitude and longitude of the receivers of the natal drainage array and the Ship Island array. Spatial Analyst tools were used to create a least cost path (LCP) model in ArcMap (ESRI, v. 10.3), which requires origin and destination locations to calculate the most conservative distance traveled between 2 points. For conservative entry distance, the origin was the last detection on the assumed natal drainage array during fall emigration, whereas the destination was the first detection on the Ship Island array during the fall emigration period. Conservative exit distance considered the origin to be the last detection on the Ship Island array during spring immigration and the destination to be the first detection on the assumed natal drainage array during spring immigration. All receiver locations from the natal drainage arrays and the Ship Island array were imported into ArcMap and individually exported as a layer, which allowed for individual selection of receivers in the LCP model (see detailed treatment of development and application of the LCP model we use in this study; 'Methods' in Supplement 2 at www.int-res.com/ articles/suppl/n037p195_supp.pdf).

\section{Travel rate}

Conservative time of travel (d) and conservative distance of travel $(\mathrm{km})$ were used to determine the conservative rate of travel $\left(\mathrm{km} \mathrm{d}^{-1}\right)$. Entry and exit rates were calculated by population unit (western and eastern) for all unique individuals as well as assumed natal river (river where fish were tagged; Pearl, Pascagoula, Escambia, Blackwater, Yellow, and Choctawhatchee). A 2-way ANOVA was performed with natal drainage $(n=6)$ and entry and exit $(n=2)$ as main effects along with the interaction term (natal drainage $x$ entry and exit). Both normality (quantile-quantile plots) and homogeneity of variance were examined (Levene's test) using SPSS (IBM, v. 23) prior to analysis. If these assumptions were violated, then the data were $\log _{10}$ transformed and re-processed. If normality and homogeneity of variance assumptions were not met afterwards, then 
ANOVA was considered robust to assumption violations and robust enough to use because the data were large and generally balanced (Underwood 1997, Field 2013). Since the interpretation of each analysis (nontransformed vs. transformed) was the same, we opted to present results where model assumptions were closest to acceptable, as there are no appropriate or strong non-parametric tests comparable to a 2-way ANOVA (Field 2013). Finally, the rate of travel for entry and exit was also plotted and visually compared by both population unit and natal river drainages.

\section{RESULTS}

\section{Gulf sturgeon on the Ship Island array}

Fish detected on the array represented both the eastern and western population units of Gulf sturgeon from 5 of the 8 core river drainages (Manson \& Hogarth 2003). Eastern Gulf sturgeon detected on the array $(\mathrm{n}=26)$ included fish from the Escambia ( $\mathrm{n}=$ 3, 1370-1778 mm FL), Blackwater ( $\mathrm{n}=$ 17, 1290-1880 mm FL), Yellow ( $\mathrm{n}=2$, 1730-1950 mm FL), and Choctawhatchee ( $\mathrm{n}=4,1370-1860 \mathrm{~mm}$ FL) rivers. Western Gulf sturgeon detected on the array $(n=35)$ included fish from both the Pearl ( $\mathrm{n}=15,1010-$ $1700 \mathrm{~mm}$ FL) and Pascagoula (n = 20, 899-1576 mm FL) rivers ('Results' in Supplement 1).

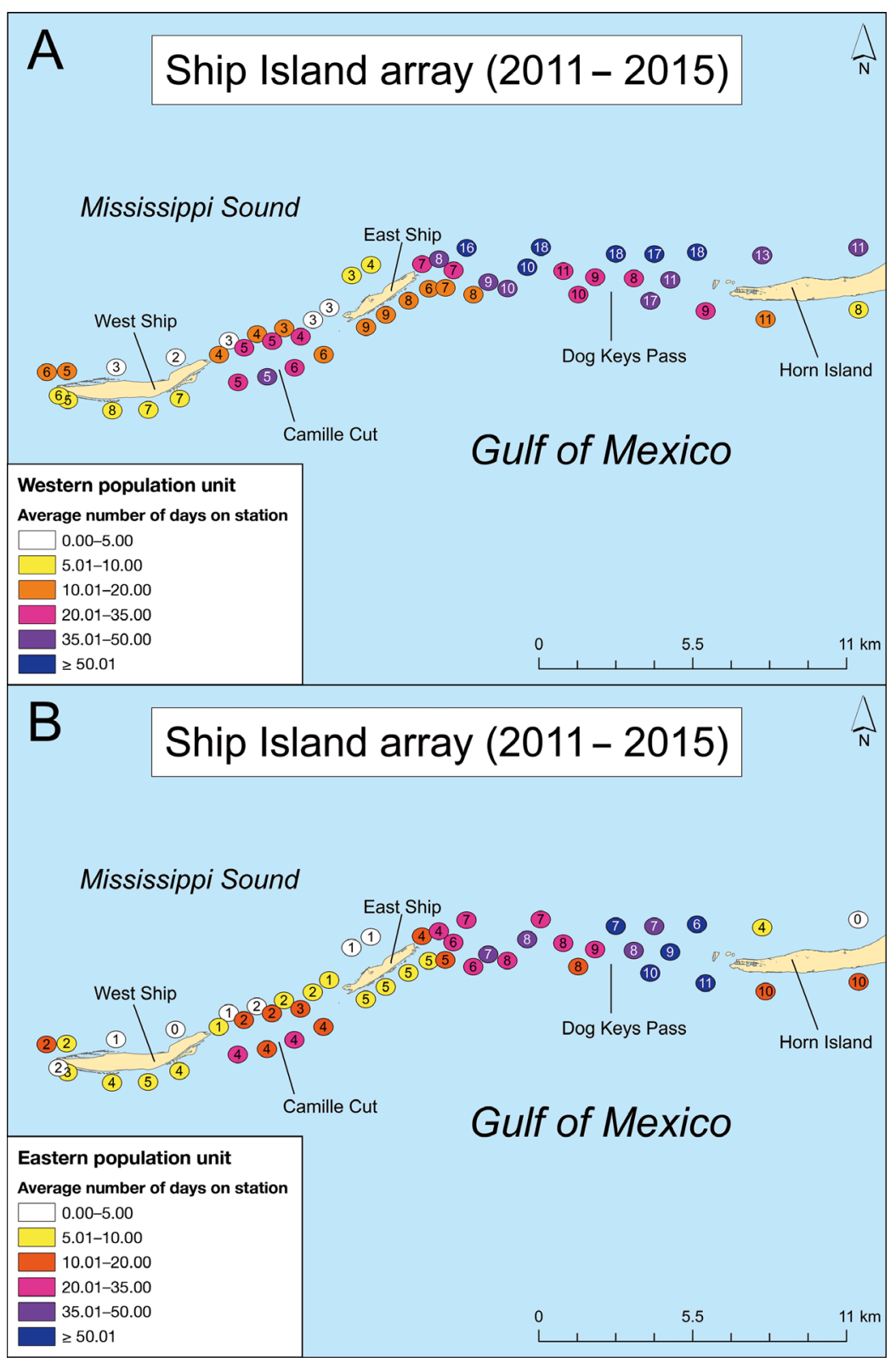

Fig. 2. Mean active days by population unit. (A) Western unit; (B) eastern unit. Numbers within circles represent mean number of active Gulf sturgeon detected on a receiver

\section{Spatial use}

For the 26 fish from the eastern population unit, active days ranged from 1 to 93, with a mean of $32.7 \mathrm{~d}$ on the array. Active days ranged from 1 to 117 for western population unit fish $(\mathrm{n}=35)$, with a mean of 37.4 active days. There was no significant difference in active days between western and eastern population units $(Z=-0.635, \mathrm{p}=0.525)$. We observed that fish from the eastern population arrived in the area monitored by the Ship Island array about 1 mo later, on average, than fish from the western population, and eastern population fish departed the area about 1 mo later, on average, than western population fish.

Spatial use of the area monitored by the Ship Island array by population unit was estimated using active fish per receiver and active days per receiver. For the western population unit, mean fish per receiver ranged from 2 to 18 individuals (Fig. 2A). The areas with the least mean fish per receiver and mean active days per receiver occur on the north side of East Ship and West Ship Islands, whereas the south side of 
these 2 zones and Horn Island areas were shown to have greater mean fish per receiver and days per receiver (Fig. 2A). Dog Keys Pass receivers had the greatest mean active fish per receiver and active days per receiver (Fig. 2A). The eastern population unit exhibited similar patterns to the western population unit with the majority of active fish per receiver and active days per receiver in Dog Keys Pass (Fig. 2B). Five receivers with $\geq 50.01 \mathrm{~d}$ with an average of 8 active fish were noted for eastern population fish, whereas 6 receivers with $\geq 50.01 \mathrm{~d}$ with an average of 16 active fish were noted for western population fish; $\geq 50.01$ active days occurred exclusively in Dog Keys Pass (Fig. 2). Receivers in areas north of East Ship and West Ship islands had the lowest mean active fish per receiver and active days per receiver. In contrast, receivers in the south area of the islands had intermediate values.

\section{Seascape connectivity}

As expected, the conservative distance traveled by fish entering and exiting the Ship Island array varied by natal river drainage, with Pascagoula fish traveling the shortest distance $(30 \mathrm{~km})$ and Choctawhatchee fish the greatest (252 km, Fig. 3). Alongshore movement of Gulf sturgeon was supported by several detections on an automated VR2W receiver close to the Gulf State Park Pier in Gulf Shores, Alabama (R. Nelson, Dauphin Island Sea Lab [DISL], pers. comm.). Natal river drainage exchange among population units was also observed, with 2 eastern population fish entering the western river systems during spring immigration: Blackwater fish A69-1303-45734 entered the Pearl River on 28 May 2014, and Escambia fish A69-9001-30598 entered the Pascagoula River on 1 April 2015.
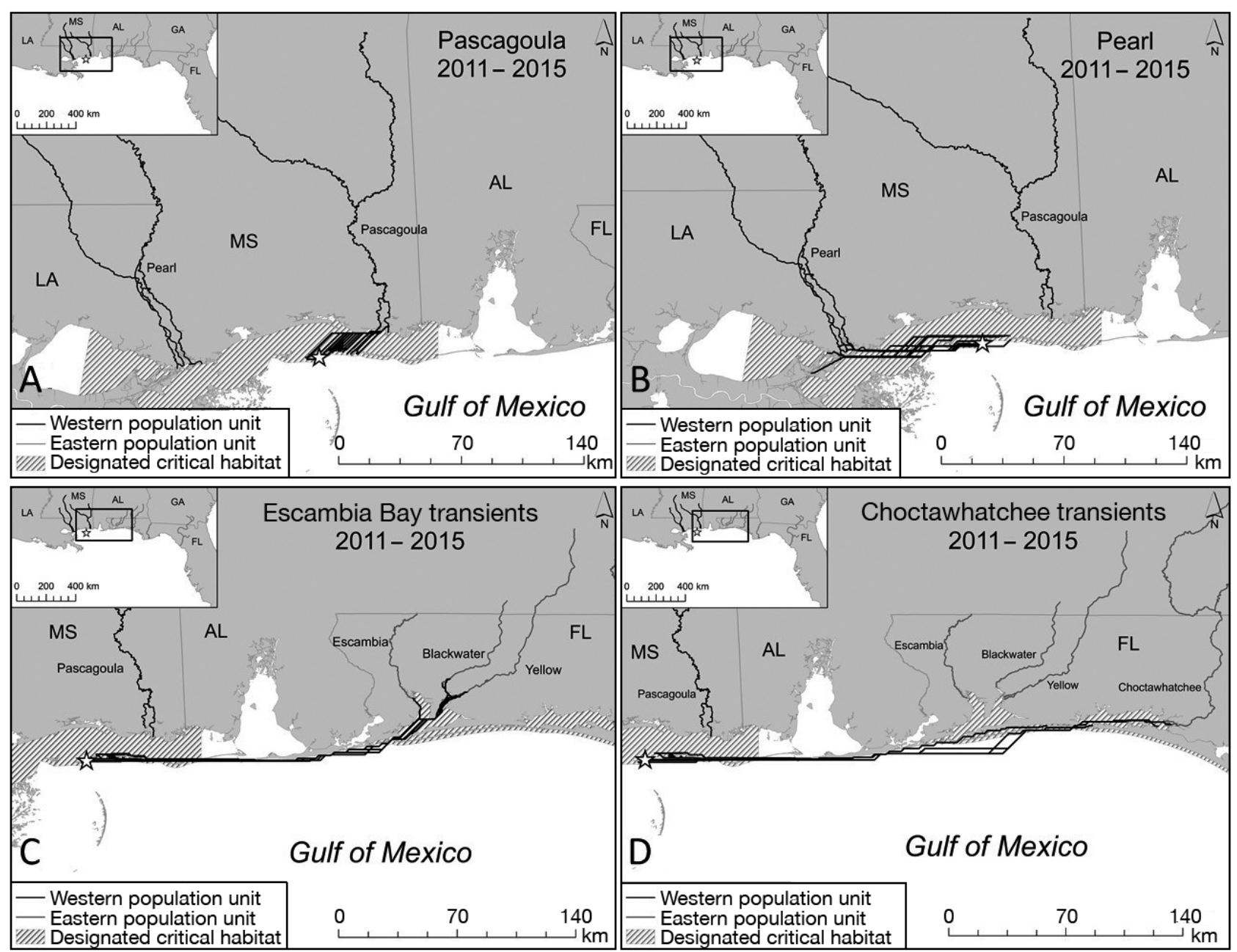

Fig. 3. Conservative Gulf sturgeon movement by core river from 2011 to 2015. (A) Pascagoula River; (B) Pearl River; (C) Escambia Bay transients; (D) Choctawhatchee River transients. From 2011 to 2015, 61 Gulf sturgeon were detected on the Ship Island array (star). Gulf sturgeon movement entering and exiting the Ship Island array/river array is represented by the thick black lines 


\section{Population units}

Rate of travel $\left(\mathrm{km} \mathrm{d}^{-1}\right)$ for both entry to and exit from $(\mathrm{n}=2$ ) the Ship Island array and 2 population units ( $\mathrm{n}=2$, west vs. east) was analyzed on nontransformed data sets. There was no significant interaction effect in the rate of travel $\left(\mathrm{km} \mathrm{d}^{-1}\right)$ to Ship Island (entry and exit $\times$ population unit, $F_{1,156}=0.407$, $\mathrm{p}=0.524$ ), thus allowing main effects to be examined separately. Rate of travel was not significantly different between natal river entry and exit periods $\left(F_{1,156}=0.793, \mathrm{p}=0.375\right)$, but it was significant between population units $\left(F_{1,156}=17.281, \mathrm{p}<0.0001\right)$. Rate of travel was significantly higher for eastern population fish when compared to western population fish (Fig. 4); there was little variance ( \pm 1 SEM) among mean entry and exit travel rates within population units.

\section{River drainage}

Rate of travel $\left(\mathrm{km} \mathrm{d}^{-1}\right)$ was also analyzed for both entry to and exit from $(n=2)$ the Ship Island array and natal river drainages $(\mathrm{n}=6)$ on $\log _{10}$-transformed data. The mean rate of travel for all rivers ranged from 2.3 to $6.2 \mathrm{~km} \mathrm{~d}^{-1}$. As there was no significant interaction effect in the rate of travel $\left(\mathrm{km} \mathrm{d}^{-1}\right)$ for the monitoring periods (entry and exit $\times$ natal river drainage, $F_{5,148}=0.559, \mathrm{p}=0.731$ ), entry and exit and natal river drainage were examined separately. Rate of travel did not differ significantly between entry and exit $\left(F_{1,148}=\right.$ $1.691, \mathrm{p}=0.195)$, meaning entry rates of travel and exit rates were relatively the same. However, natal river drainages did differ significantly $\left(F_{5,148}=5.045\right.$, $\mathrm{p}<0.0001$ ), and the Sidak post hoc tests showed that

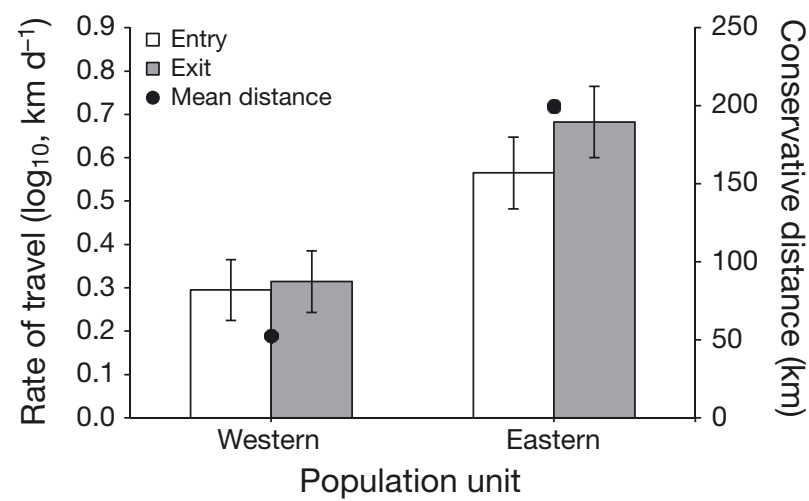

Fig. 4. Rate of travel $\left(\log _{10}, \mathrm{~km} \mathrm{~d}^{-1}\right)$ by entry to and exit from Ship Island and population unit compared to the mean distance $(\mathrm{km})$ traveled. Error bars represent \pm 1 SEM, and black dots represent the mean conservative distance $(\mathrm{km})$

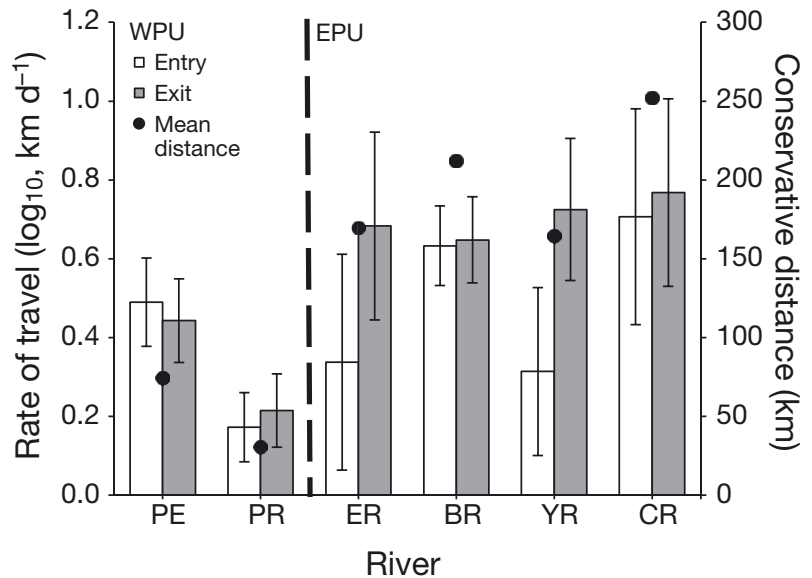

Fig. 5. Rate of travel $\left(\log _{10}, \mathrm{~km} \mathrm{~d}^{-1}\right)$ by entry to and exit from Ship Island and river drainage compared to mean conservative distances $(\mathrm{km})$ traveled. PE: Pearl River; PR: Pascagoula River; ER: Escambia River; BR: Blackwater River; YR: Yellow River; CR: Choctawhatchee River. The western population unit (WPU) is to the left of the dashed line, and the eastern population unit (EPU) is to the right. Error bars represent \pm 1 SEM, and black dots represent the mean conservative distance $(\mathrm{km})$ traveled

the Blackwater River fish had significantly higher travel rates compared to the Pascagoula River fish $(\mathrm{p}<$ 0.0001, Fig. 5). There was little variance ( \pm 1 SEM) in entry and exit travel rates, but travel rate variance among natal river drainages was high (Fig. 5).

\section{DISCUSSION}

About $41 \%$ of the Gulf sturgeon that were detected on the Ship Island array from 2011 to 2015 were individuals from the eastern population unit, suggesting Ship Island, Dog Keys Pass, and western Horn Island serve as critical overwintering habitat for both population units. Although previous studies suggested these large-scale migration events are rare (Parauka et al. 2011, Havrylkoff et al. 2012, but see USFWS 2015), we suggest otherwise. Foraging was assumed to occur in these regions of heavy activity as the fish remained in small areas for extended periods of time, which resembled assumed foraging activity described in previous studies (Fox et al. 2002, Parauka et al. 2011, Peterson et al. 2013, 2016). Furthermore, reduced Gulf sturgeon activity was observed along the north side and intermediate activity on the south side of West Ship and East Ship islands. This may indicate that Gulf sturgeon rarely use this portion of available habitat as their main foraging environment but rather for passage to more suitable feeding habitat. This is supported by both passive (Vick et al. 
2018) and manual tracking studies that observed Gulf sturgeon concentrated near the ends and passes of several Mississippi barrier islands (Rogillio et al. 2007, Ross et al. 2009).

Although the conservative distance from natal river arrays to the Ship Island array ranged from $30 \mathrm{~km}$ (Pascagoula River mouth) to as far as $262 \mathrm{~km}$ (Choctawhatchee River mouth), rates of travel were not significantly different among natal rivers for fall and spring (exit and entry periods), which is interesting because of the obvious differences in distances among natal rivers. Furthermore, travel rate was generally higher in eastern population fish, with Blackwater River fish having significantly higher travel rates than Pascagoula River fish, although these eastern population fish must also travel markedly further than western population fish to reach Ship Island overwintering habitat, as entry rates were not different.

Although more spatially explicit work still needs to be done, alongshore movement of Gulf sturgeon in the shallow nearshore marine environment appears to be the main pathway traveled by detected individuals. Migration to and from overwintering habitat has been observed in previous manual and passive tracking studies (Fox et al. 2002, Rogillio et al. 2007, Ross et al. 2009, Parauka et al. 2011, USFWS 2015, Peterson et al. 2018); individual migration may occur at steady speeds or in bursts of higher speed followed by sustained feeding (Parauka et al. 2011). Although it is possible that the fish swam at a constant speed to the Ship Island array, it is highly unlikely; individuals most likely swam in higher speed bursts and stopped to feed in suitable foraging areas. Several fish from the eastern population unit were detected in shallow nearshore areas in Gulf Shores, Alabama, prior to entering the Ship Island array (R. Nelson, DISL, pers. comm.). This observation suggests that emigrating Gulf sturgeon may use nearshore marine environments for alongshore movement to reach overwintering habitat.

Gulf sturgeon may stray from their natal rivers in the spring in favor of a river that is near overwintering areas (Dugo et al. 2004, Parauka et al. 2011). This behavior was observed in the present study; however, most fish returned to their assumed natal river drainages in the spring. Regardless of natal drainage straying, movement to and from western barrier islands by either population unit results in the accumulation of marine carbon in sub-adult and adult individuals through feeding on benthic invertebrates associated with the Mississippi's barrier islands. As individuals immigrate to rivers in the spring, marine carbon is transported upriver and released into the freshwater environment through excretion, spawn- ing, and death of immigrating individuals (Loreau et al. 2003, Leibold et al. 2004). This uptake of marine carbon also functionally connects habitats of western and eastern population units. Therefore, Gulf sturgeon can be viewed as part of a larger meta-community formed by links of interacting organisms among local communities or through spatial and temporal connectivity (Loreau et al. 2003, Leibold et al. 2004). If this movement pattern is disconnected, then largescale ecological issues may develop for these drainages because of changes in carbon cycling (Schindler \& Smits 2017, Wolanski 2017). Gulf sturgeon habitat for both population units must be protected from future anthropogenic activities to ensure that vital connectivity between marine and freshwater environments remains for this threatened anadromous species.

Ship Island was observed to be heavily used by both population units of Gulf sturgeon during overwintering. Designated critical habitat of Ship Island, as well as the other barrier islands of the Mississippi Sound, should be maintained, as these islands represent assumed foraging habitat. We suggest that regulatory agencies should limit habitat disturbance to times of the year when Gulf sturgeon are not actively occupying and feeding (i.e. mid-April through mid-September, when fish are upriver), and we suggest that sand dredged for any ship channel maintenance should be redistributed to areas that will replenish the barrier island chain. During this study period, several eastern population Gulf sturgeon were detected on acoustic arrays in Mobile Bay, Alabama (R. Nelson, DISL, pers. comm.), which may imply that suitable foraging habitat exists within Mobile Bay. Knowledge of Gulf sturgeon spatial ecology has increased greatly since species listing and critical habitat designation, and research on Gulf sturgeon spatial use should continue, as it may aid in population recovery (Rudd et al. 2014).

Acknowledgements. We thank P. Grammer, J. M. Havrylkoff, P. Mickle, J. Green, T. Moncrief, M. Andres, A. Fogg, S. Ashworth, E. Satterfield, C. Matten, M. Lowe, C. Griffin, B. Lewis, S. George, A. Katzenmeyer, J. Collins, and J. Killgore for field and logistical assistance during the study. We thank G. Constant, K. Kimmel, C. Doolittle, A. Baer, A. Kaeser, J. VanVrancken, F. Parauka, A. Robydek, K. Herrington, S. Bolden, D. Fox, N. Willett, and R. Nelson for providing us with telemetry data. The NOAA Gulf sturgeon database provided data essential to this study. This project was funded by a subcontract from USACE-Mobile District (no. W912HZ-12-C-0045), and we appreciate the professional oversight of this project by S. Rees and J. McDonald and the review of an earlier draft of the paper by B. Zettle and A. Harrison. This research was conducted under USM Institute of Animal Care and Use Committee nos. 07081501, 09091702, 11092209, and 14091801. Permission to publish was provided by the Chief of Engineers. 


\section{LITERATURE CITED}

Ahrens RNM, Pine WE (2014) Informing recovery goals based on historical population size and extant habitat: a case study of the Gulf sturgeon. Mar Coast Fish 6: 274-286

Altinok I, Grizzle JM (2001) Effects of brackish water on growth, feed conversion, and energy absorption efficiency by juvenile euryhaline and freshwater stenohaline fishes. J Fish Biol 59:1142-1152

Baremore IE, Rosati JD (2013) Gulf sturgeon standardized abundance and mortality study: year two report. NOAA Tech Memo NMFS-SEFSC-642

Berkström C, Lindborg R, Thyresson M, Gullström M (2013) Assessing connectivity in a tropical embayment: fish migrations and seascape ecology. Biol Conserv 166: 43-53

Brooks RA, Sulak KJ (2005) Quantitative assessment of benthic food resources for juvenile Gulf sturgeon, Acipenser oxyrinchus desotoi in the Suwannee river estuary, Florida, USA. Estuaries 28:767-775

Bryan-Brown DA, Brown CJ, Hughes JM, Connolly RM (2017) Patterns and trends in marine population connectivity research. Mar Ecol Prog Ser 585:243-256

Dugo MA, Kreiser BR, Ross ST, Slack WT, Heise RJ, Bowen BR (2004) Conservation and management implications of fine-scale genetic structure of Gulf sturgeon in the Pascagoula River, Mississippi. J Appl Ichthyol 20:243-251

Edwards RE, Parauka FM, Sulak KJ (2007) New insights into marine migration and winter habitat of Gulf sturgeon. Am Fish Soc Symp 56:183-196

Field A (2013) Discovering statistics using IBM SPSS Statistics, 4th edn. Sage, London

Fox DA, Hightower JE, Parauka FM (2000) Gulf sturgeon spawning migration and habitat in the Choctawhatchee River system, Alabama-Florida. Trans Am Fish Soc 129: 811-826

Fox DA, Hightower JE, Parauka FM (2002) Estuarine and nearshore marine habitat use of Gulf sturgeon from the Choctawhatchee River system, Florida. Am Fish Soc Symp 28:111-126

Karman GC, Macko SA (1998) Contribution of marinederived organic matter to an Atlantic coast, freshwater, tidal stream by anadromous clupeid fishes. J N Am Benthol Soc 17:277-285

* Grammer PO, Mickel PF, Peterson MS, Havrylkoff JM, Slack WT, Leaf RT (2015) Activity patterns of Gulf sturgeon (Acipenser oxyrinchus desotoi) in the staging area of the Pascagoula River during fall outmigration. Ecol Freshwat Fish 24:553-561

*Gu B, Schell DM, Frazer T, Hoyer M, Chapman FA (2001) Stable carbon isotope evidence for reduced feeding of Gulf of Mexico sturgeon during their prolonged river residence period. Estuar Coast Shelf Sci 53:275-280

Havrylkoff JM, Peterson MS, Slack WT (2012) Assessment of the seasonal usage of the lower Pascagoula River estuary by Gulf sturgeon (Acipenser oxyrinchus desotoi). J Appl Ichthyol 28:681-686

Heise RJ, Slack WT, Ross ST, Dugo MA (2004) Spawning and associated movement patterns of Gulf sturgeon in the Pascagoula River drainage, Mississippi. Trans Am Fish Soc 133:221-230

Heise RJ, Slack WT, Ross ST, Dugo MA (2005) Gulf sturgeon summer habitat use and fall migration in the Pascagoula River, Mississippi, USA. J Appl Ichthyol 21:461-468
LeBreton GTO, Beamish FWH (2004) Growth, bioenergetics and age. In: LeBreton GTO, Beamish FWH, McKinley RS (eds) Sturgeons and paddlefish of North America. Kluwer, Dordrecht, p 195-216

Leibold MA, Holyoak M, Mouqet N, Amarasekare P and others (2004) The metacommunity concept: a framework for multi-scale community ecology. Ecol Lett 7:601-613

Loreau M, Mouquet N, Holt RD (2003) Meta-ecosystems: a theoretical framework for a spatial ecosystem ecology. Ecol Lett 6:673-679

Manson C, Hogarth WT (2003) Endangered and threatened wildlife and plants: designation of critical habitat for the Gulf sturgeon. Fed Regist 68:13370-13495

Mason WT, Clugston JP (1993) Foods of the Gulf sturgeon in the Suwannee River, Florida. Trans Am Fish Soc 122: 378-385

* Merz JE, Moyle PB (2006) Salmon, wildlife, and wine: marine-derived nutrients in human-dominated ecosystems of central California. Ecol Appl 16:999-1009

* Mickle PF, Schaefer JF, Adams SB, Kreiser BR (2010) Habitat use of age 0 Alabama shad in the Pascagoula River drainage, USA. Ecol Freshwat Fish 19:107-115

* Naiman RJ, Bilby RE, Schindler DE, Helfield JM (2002) Pacific salmon, nutrients, and the dynamics of freshwater and riparian ecosystems. Ecosystems 5:399-417

* Parauka FM, Duncan MS, Lang PA (2011) Winter coastal movement of Gulf of Mexico sturgeon through northwest Florida and southeast Alabama. J Appl Ichthyol 27: 343-350

*Peterson MS, Havrylkoff JM, Grammer PO, Mickle PF, Slack WT, Yeager KM (2013) Macrobenthic prey and physical habitat characteristics in a western Gulf sturgeon population: differential estuarine habitat use patterns. Endang Species Res 22:159-174

Peterson MS, Havrylkoff JM, Grammer PO, Mickle PF, Slack WT (2016) Consistent spatio-temporal estuarine habitat use of a western population of the Gulf sturgeon. Trans Am Fish Soc 145:27-43

*Peterson MS, Slack WT, Grammer PO, Havrylkoff JM (2018) Use of non-island, shallow nearshore beach environments by Gulf sturgeon within Mississippi Sound, USA. J Appl Ichthyol 34:3-11

Ray GC (2005) Connectivities of estuarine fishes to the coastal realm. Estuar Coast Shelf Sci 64:18-32

Robydek A, Nunley M (2011) Determining marine migration patterns and behavior of the Gulf sturgeon in the Gulf sturgeon critical habitat of the Gulf testing and training range and Santa Rosa Island complex. 13th Annual Gulf Sturgeon Workshop, Niceville, FL, 16-18 November 2011

Rogillio HE, Ruth RT, Behrens EH, Doolittle CN, Granger WJ, Kirk JP (2007) Gulf sturgeon movements in the Pearl River drainage and the Mississippi Sound. N Am J Fish Manage 27:89-95

Ross ST, Slack WT, Heise RJ, Dugo MA and others (2009) Estuarine and coastal habitat use of Gulf sturgeon (Acipenser oxyrinchus desotoi) in the north-central Gulf of Mexico. Estuar Coast 32:360-374

* Rudd MB, Ahrens RNM, Pine WE III, Bolden SK (2014) Empirical, spatially explicit natural mortality and movement rate estimates for the threatened Gulf sturgeon (Acipenser oxyrinchus desotoi). Can J Fish Aquat Sci 71: $1407-1417$

Schindler DE, Smits AP (2017) Subsidies of aquatic resources in terrestrial ecosystems. Ecosystems 20:78-93 
Sheaves M (2009) Consequences of ecological connectivity: the coastal ecosystem mosaic. Mar Ecol Prog Ser 391: $107-115$

Stabile J, Waldman JR, Parauka F, Wirgin I (1996) Stock structure and homing fidelity in Gulf of Mexico sturgeon (Acipenser oxyrinchus desotoi) based on restriction fragment length polymorphism and sequence analyses of mitochondrial DNA. Genetics 144:767-775

Sulak KJ, Clugston JP (1998) Early life history stages of Gulf sturgeon in the Suwannee River, Florida. Trans Am Fish Soc 127:758-771

Sulak KJ, Randall MT, Edwards RE, Summers TM and others (2009) Defining winter trophic habitat of juvenile Gulf sturgeon in the Suwannee and Apalachicola rivermouth estuaries, acoustic telemetry investigations. J Appl Ichthyol 25:505-515

Sulak KJ, Berg JJ, Randall M (2012) Feeding habitats of the Gulf sturgeon, Acipenser oxyrinchus desotoi, in the Suwannee and Yellow rivers, Florida, as identified by multiple stable isotope analyses. Environ Biol Fishes 95: 237-258

Sulak KJ, Parauka F, Slack WT, Ruth RT, Randall MT, Luke K, Price ME (2016) Status of scientific knowledge, recovery progress, and future research directions for the Gulf sturgeon, Acipenser oxyrinchus desotoi Vladykov, 1955. J Appl Ichthyol 32:87-161

Underwood AJ (1997) Experiments in ecology: their logical design and interpretation using analysis of variance. Cambridge University Press, Cambridge

Editorial responsibility: Steven Cooke, Ottawa, Ontario, Canada
USFWS (US Fish and Wildlife Service) (1991) Endangered and threatened wildlife and plants; determination of a threatened status for the Gulf sturgeon. Fed Regist 56: 49653-49658

USFWS (2015) Exposure and injuries to threatened Gulf sturgeon (Acipenser oxyrinchus desotoi) as a result of the Deepwater Horizon oil spill, draft preliminary technical report. USFWS, Fairhope, AL

USFWS \& GSMFC (Gulf States Marine Fisheries Commission) (1995) Gulf sturgeon recovery plan. USFWS, Atlanta, GA

Vick PE, Peterson MS, Slack WT, Grammer PO (2018) Occupancy patterns of Gulf sturgeon, Acipenser oxyrinchus desotoi, associated with Ship Island, Mississippi. J Coast Res 34:640-650

Wolanski E (2017) Bounded and unbounded boundaries untangling mechanisms for estuarine-marine ecological connectivity: scales of $\mathrm{m}$ to $10,000 \mathrm{~km}$ - a review. Estuar Coast Shelf Sci 198:378-392

*Wooley CM (1985) Evaluation of morphometric characters used in taxonomic separation of Gulf of Mexico sturgeon, Acipenser oxyrhynchus desotoi. In: Binkowski F, Daroshov SI (eds) North American sturgeons: developments in environmental biology of fishes, Vol 6. Dr. W. Junk, Dordrecht, p 97-103

Wooley CM, Crateau EJ (1985) Movement, microhabitat, exploitation, and management of Gulf of Mexico sturgeon, Apalachicola River, Florida. N Am J Fish Manage 5:590-605

Submitted: March 20, 2018; Accepted: September 3, 2018 Proofs received from author(s): October 18, 2018 